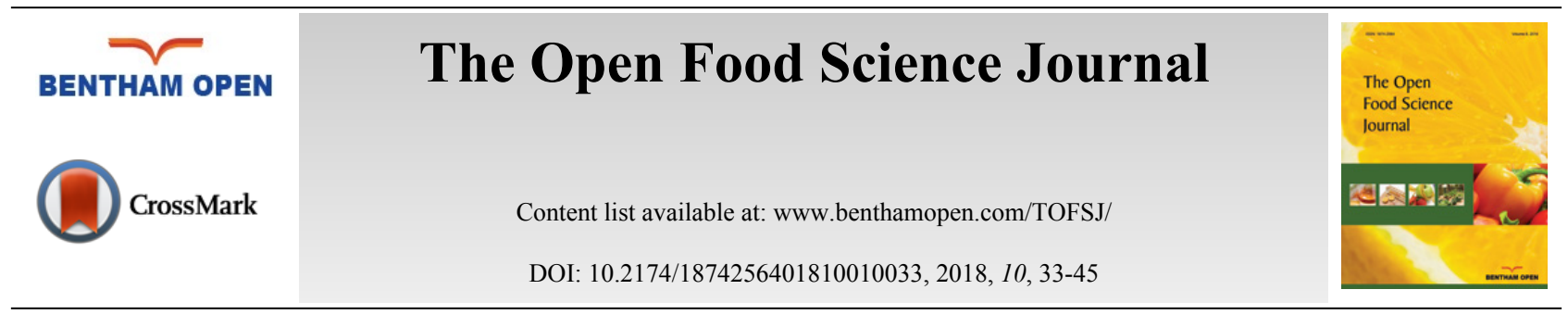

RESEARCH ARTICLE

\title{
Morphological, Molecular, Biochemical and Nutritional Characterization of Three Major Thais Species from the Sindh Coast of Pakistan
}

Syed Abid Ali ${ }^{1, *}$, , Fozia Humayun ${ }^{1, \S}$, Iqra Munir ${ }^{1}$, Shakil Ahmad ${ }^{1}$, Zarrien Ayub ${ }^{2}$, Habib Fatima ${ }^{3}$, Lakht-e- Zehra ${ }^{4}$ and Muhammad Samee Haider ${ }^{4}$

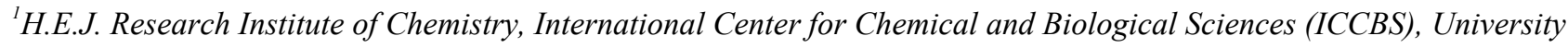
of Karachi, Karachi-75270, Pakistan

${ }^{2}$ Center of Excellence for Marine Biology, University of Karachi, Karachi 75270, Pakistan

${ }^{3}$ Department of Physiology, University of Karachi, Karachi 75270, Pakistan;

${ }^{4}$ Food \& Marine Resources Research Centre, PCSIR Labs Complex, Karachi 75280, Pakistan

Received: October 07, 2018

Revised: November 20, 2018

Accepted: November 26, 2018

Abstract:

Objective:

The present study was conducted to investigate the biomass assessment, morphological and molecular identification, nutritive status and biochemical characterization of three major Thais species (T. bufo, T. hippocastanum and T. rudolphi) from the Sindh Coast, Pakistan.

\section{Methods:}

Samples were collected from Buleji and Paradise Point at the Sindh Coast. Species were identified morphologically as well as genetically by amplifying two mitochondrial 16S rDNA \& Cytochrome Oxidase I (COI) and one nuclear (Histone H3) genes. Shell microstructure and chemistry were also studied by scanning electron microscopy and Energy Dispersive X-ray spectrometry (EDX). The body muscle was dissected and used for nutritional composition determination such as estimation of total protein, carbohydrates, lipids, protein fingerprinting by Sodium Dodecyl Sulfate-Polyacrylamide Gel Electrophoresis (SDS-PAGE) and Size-Exclusion Fast Protein Liquid Chromatography (SEC-FPLC), amino acid and fatty acid analysis.

\section{Results:}

Nutritionally, the total protein was found to be the major content followed by carbohydrate and lipid in the three Thais sp. The presence of medicinally important hemocyanin as abundant hemolymph protein was confirmed via SDS-PAGE and SEC FPLC. Nine different types of fatty acids and a high concentration of essential amino acids were also determined.

\section{Conclusion:}

Our findings suggest that Thais $s p$. are nutritionally rich and can be consumed as a valuable marine resource to overcome the malnutrition problem in developing countries.

Keywords: Gastropods, Proteins, Amino acids, Alternative food, Thais, Sindh coast.

\footnotetext{
"Address correspondence to this author at the H.E.J. Research Institute for Chemistry, International Center for Chemical and Biological Sciences (ICCBS), University of Karachi, Karachi-75270, Pakistan; Tel:0092-21-99261720; Fax:0092-2134819018-19; Email: abid.ali@iccs.edu

$\S$ shared first author
} 


\section{INTRODUCTION}

Sindh coast of Pakistan is highly enriched with mangroves, which displays a diverse ecosystem and thus stands as a homeland for free-living, climbing, crawling, burrowing and sessile organisms. The distribution and availability of gastropods at three different sites of Sindh coast (i.e. Sandspit, Clifton and Port Qasim) along with the other invertebrates show that the gastropods and amphipods constituted around $70 \%$ of population at Sandspit, whereas at Port Qasim, gastropods make up to even $80 \%$ of population [1]. The presence of marine gastropods was reported earlier from different coastal sites of Sindh including: Thais carnifera, Thais hipocastanum, Thais bufo, Thais rudolphi, Thais tissoti, Turricula javana and Babylonia spirata [2].

The coastline of Pakistan, which is $1045 \mathrm{~km}$ long, extends from Sir Creek in the southeast to Jiwani in the northwest bordering the Arabian Sea. The Sindh coast covers $241 \mathrm{~km}$ and Baluchistan coast $644 \mathrm{~km}$ of Pakistani coastline. The coastal zone of Pakistan has rocky, sandy and muddy profiles at various locations along the coast like Buleji, West Wharf and Manora Island [3]. Tides along the coast of Pakistan are semidiurnal, while the tidal range varies from $1.8 \mathrm{~m}$ to $3.2 \mathrm{~m}$. The tidal range at Karachi port is around $2.3 \mathrm{~m} \mathrm{[4].}$

Seafood represents a large class of edible species of gastropods which are frequently consumed worldwide and is a healthy choice of food since it possesses high-quality proteins in comparison to those present in meat and poultry. Malnutrition, which is a serious threat to the developing countries, can be overcome if the edible species of gastropods are exploited properly [5 - 7]. The biochemical composition of edible species of gastropods exhibits its nutritional values and the dietary sources of these gastropods reflect the chemical diversity of metabolites found in some mollusks $[6,8,9]$. Besides medicinal importance [10 - 12], richness of marine gastropods in high-quality status as food also cannot be neglected.

The genus Thais belongs to the Rapaninae - a subfamily of the Muricidae which is one of the most extensively studied families of the Gastropods in terms of prevalence, species distribution and identification by molecular sequencing and phylogenetic analysis [13 - 15]. Among the families of mollusks reported so far, the Muricidae are the most diverse family in terms of representing the commercially and economically significant species [16]. Thais (the rock snails) feeds on barnacles, oysters and other mollusks, and thus being a pest, damages Oyster farms. Most of the species of Muricids are carnivores since they feed on other mollusks, invertebrates and anthozoans etc. In the past, Greeks and Romans used to extract the precursor of traditional Tyrian purple dye from the hypobranchial glands present in the Muricids, which is said to perform defensive function [14]. Moreover, some species of Thais are used as shellfish pests and are thus economically very important. On the other hand, some of them are also reported as a potential source of anticancer drugs [15].

Marine gastropods develop common morphological characteristics e.g. large apertural teeth or increased shell thickness for defense against shell-crushing predators. Several environmental factors such as extreme temperature, desiccation stress etc. are also correlated with the shell pattern, color and morphology. The habitat of shells also accounts for such changes. Most marine gastropods possess simple shells and are deprived of easily identifiable morphological structure. Moreover, the plasticity in shell morphology makes the identification more difficult [17, 18]. Therefore, the molecular basis established by DNA sequencing and barcoding in this regard is very fruitful and recommended strategy [19].

In this context, the present study aims (i) to compare the morphological and molecular identification of the three predominant species of genus Thais (i.e. T. bufo, T. hippocastanum and T. rudolphi), (ii) present their biomass and distribution from the two coastal sites of Pakistan (i.e. Buleji and Paradise point), (iii) establish species level identification via Polymerase Chain Reaction (PCR)-based amplification of the two mitochondrial genes 16S rDNA and COI along with one nuclear gene H3, (iv) construct the phylogenetic relationships of the subjected Thais sp. with the other reported Thais sp. in the National Center for Biotechnology Information (NCBI) Genbank, and (v) evaluate the chemotaxonomy and the nutritive profiles i.e. total protein, carbohydrate, lipid, amino acid and fatty acid composition in the tissue of Thais sp.

\section{MATERIALS AND METHODS}

\subsection{Sampling}

In the present study, three major species of genus Thais (i.e. T. bufo, T. hippocastanum and T. rudolphi) were collected from the low tidal zone of Buleji and Paradise Point. Buleji is in the southwest of Karachi about $20 \mathrm{~km}$ from 
the center of the city between Hawks Bay and Paradise Point bordering the Arabian Sea. It lies at latitude $24^{\circ} 50^{\prime} \mathrm{N}$ and longitude $66^{\circ} 48^{\prime} \mathrm{E}$ of Karachi near the fishing village of Buleji. The ledge is divisible into two parts, one which faces the open ocean and thus is exposed to high wave action. The second part of the ledge on the west is considered protected, as it is exposed to less wave action. The coast has different types of habitats such as tide pools of varying sizes (with sandy, muddy and rocky bottoms), exposed and sheltered rocks crevices, boulders, pebbles, muddy and sandy portions. The ledge has rocky substratum with few sandy pockets. The intertidal zone of rocky shore is mainly composed of sedimentary rocks. Thus, it has been extensively studied for being the diverse habitat of various species and for its biomass of animals [20, 21]. Second sampling site, the Paradise Point is situated at $24^{\circ} 50^{\prime} \mathrm{N}$ and $66^{\circ} 48^{\prime} \mathrm{E}$ of Karachi between Buleji and Nathiagali (Fig. 1A).

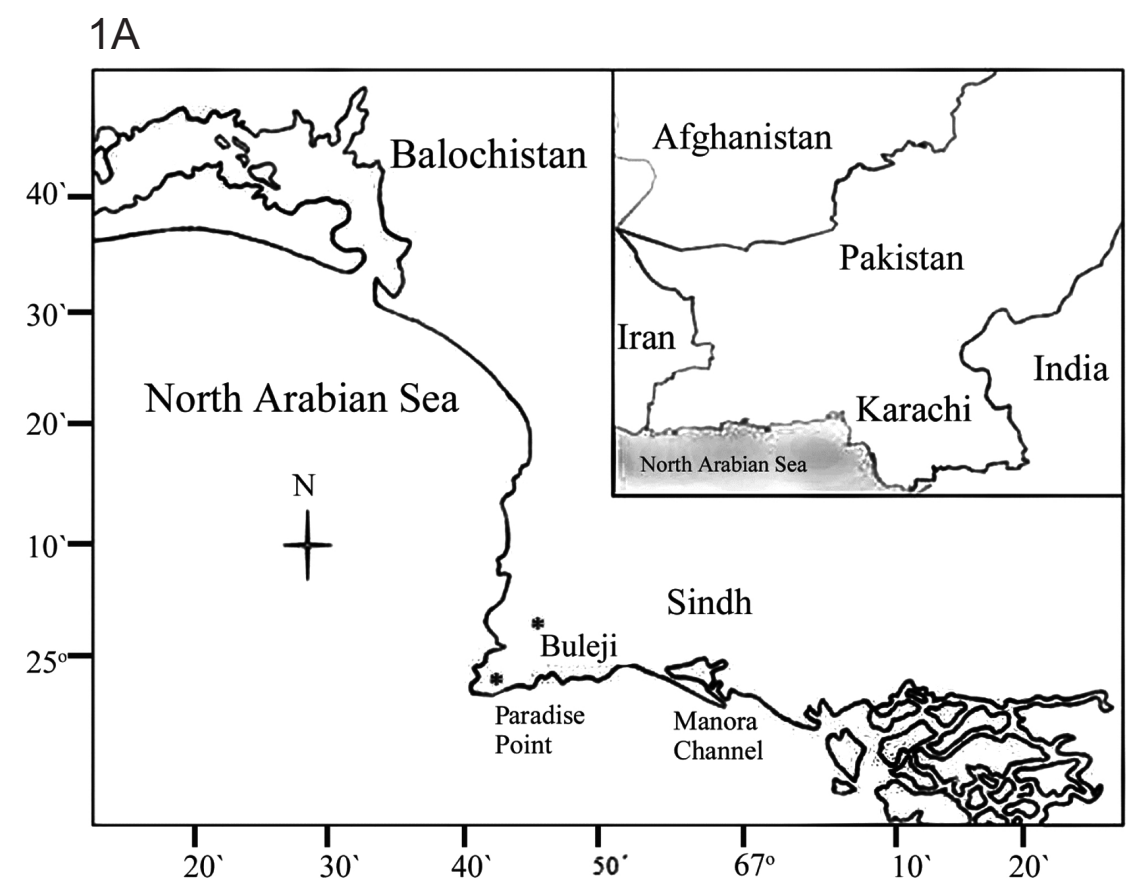

1B
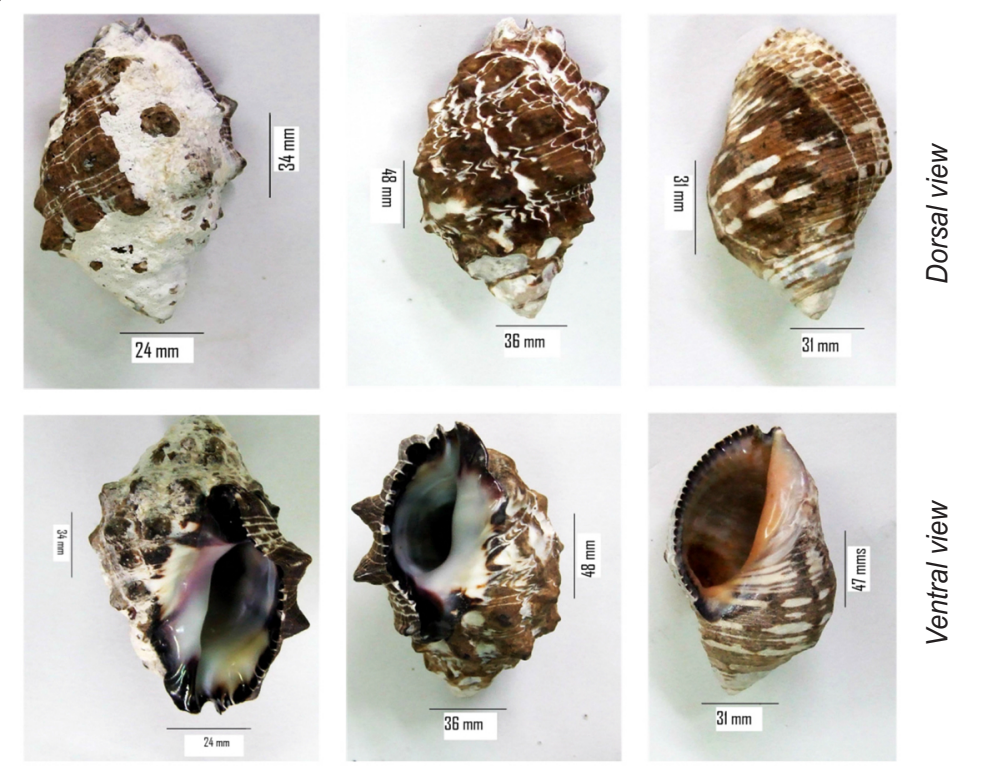

Fig. (1). (A) Map showing the collection sites, Buleji and Paradise Point on the coast of Karachi. Inset: showing the coastline of Pakistan. (B) Dorsal and ventral view of the shells of three major Thais sp. collected from Buleji site Karachi, Pakistan and used for shell-based morphological identification. 
The sampling was conducted at each month from October 2013 to September 2014 by transect line and quadrate method at Buleji (Fig. 1B). The three transect lines, $\mathrm{A}, \mathrm{B}$ and $\mathrm{C}$ were placed in the mid of high, mid and low tidal zone, respectively. A total of 3 quadrates $(50 \times 50 \mathrm{~cm})$ were taken from each transect line. All the gastropods within each quadrate were removed and placed in pre-labeled plastic bags and brought to the laboratory. In the laboratory, animals were washed with tap water, counted, weighed wet and tissue dried at $70{ }^{\circ} \mathrm{C}$. The gastropods were initially identified with the help of literature described elsewhere [22 - 24]. The specimen collection was also made at Paradise Point during the same period. Due to the narrow intertidal zone, the quadrats were randomly placed in Paradise point. A total of 6 quadrats were placed in the area and the gastropods collected were brought to the laboratory.

\subsection{Scanning Electron Microscopy (SEM)}

Cross-sections of the shells were obtained by cutting it with a razor blade. Samples were gold coated up to $300 \AA$ with JEOL JFC 1500 fine coater and observed with a JEOL JSM-6380A (Japan), analytical SEM operating at $20 \mathrm{kV}$. Images were observed via SEM main menu. Elemental characterization of each shell was achieved by Energy Dispersive X-ray spectrometry (EDX) mode (9335 emission peaks per second). Scanning was performed under high vacuum. Data was analyzed by EDS-SEM associated analytical program EDS Analysis Station [25].

\subsection{Genomic DNA Extraction, PCR Amplification and RFLP Analysis}

The soft foot tissue was removed from the shell. The dissected tissues were immediately crushed in liquid nitrogen using mortar and pestle and were transferred in pre-labeled $1.0 \mathrm{ml}$ eppendorf tubes and then stored at $-20^{\circ} \mathrm{C}$ till further use. Isolation of genomic DNA from tissue was performed using the genomic DNA purification kit (Promega, USA) following the protocol suggested by the manufacturer. The isolated genomic DNA was evaluated for its quality and quantity using Nano-Drop (ND 2000, Thermo Scientific, USA).

Two mitochondrial (COI and 16S rDNA) and one nuclear Histone $\left(\mathrm{H}_{3}\right)$ genes were amplified using PCR (Master cycler ProS, Eppendorf Germany) using PCR amplification kit (KAPA Biosystems, USA). The set of primer sequences was used as demonstrated [26, 27], synthesized and obtained from Eurofins (Operon, USA). Sequence information of primers, PCR reaction mix, thermal conditions and the product sizes are summarized (Table S1). The PCR products were visualized by electrophoresis on a $2 \%$ agarose gel along with $1 \mathrm{~kb}$ and Ultralow DNA ladder (Fermentas, USA). The gel was run at $100 \mathrm{~V}$ for $45 \mathrm{~min}$ and followed by observation of bands on UV transilluminator (UVP, UK) after ethidium bromide stain. For Restriction Fragment Length Polymorphism (RFLP) analysis, restriction enzyme Alu-I (Promega, USA) was selected by utilizing the virtual cutting site (Restriction Mapper V3, Available On-line) in 16S rDNA and COI genes. The total reaction of enzyme digest was prepared in $20 \mu \mathrm{l}$. The components were mixed gently by pipetting before and after adding the enzyme. The reaction tubes were kept on incubation at $37{ }^{\circ} \mathrm{C}$ for $4 \mathrm{~h}$ as mentioned in the protocol provided by the manufacturer. 6x loading dye (Fermentas, USA) was added with Reaction mix followed with $2 \%$ agarose gel as mentioned above.

\subsection{DNA Sequencing and Phylogeny}

The purified PCR products were also subjected for DNA sequencing. For sequencing, amplified PCR products were purified using DNA purification kit (Promega, USA). Big Dye terminator chemistry was used to run samples on Genetic Analyzer (Model - 3130, Applied BioSystems, USA) at the Centralized Science Laboratory (CSL), University of Karachi. Sequence alignment was made using software Sequencing Analysis v512. The preliminary databank searching of the established sequences was performed via nBLAST server at NCBI. Multiple sequence alignments were generated using ClustalW. Phylogenetic analyses of datasets were conducted to assess differences among the studied species and related species with $16 \mathrm{~S}$ rDNA and COI gene sequences available on NCBI Genbank. The sequences obtained for the three Thais $s p$. were analyzed using MEGA7. The evolutionary history and evolutionary distances were inferred using the Neighbor-Joining method and Maximum Composite Likelihood method, respectively [28, 29].

\subsection{Protein Fingerprinting Using SDS PAGE \& SEC FPLC}

Crude hemolymph proteins of three Thais $s p$ were also subjected to Native and SDS-PAGE analysis using PROTEAN $^{\circledR} 3$ Cell (Bio-Rad Lab, UK). The Native-PAGE allows separation proteins based on mass to charge (m/z) ratio with the retention of protein's high ordered structure and activity. It provides the information of subunits/ charge on the protein. Whereas SDS-PAGE separates the protein purely based on their molecular mass. Whole body tissue samples (mainly comprises of total hemolymph) were homogenized in $100 \mathrm{mM}$ phosphate buffer, $\mathrm{pH} 7.5$ (1:10, w/v) 
and centrifuged at $14000 \times \mathrm{g}$ for $15 \mathrm{~min}$ at $4{ }^{\circ} \mathrm{C}$. The supernatant after protein estimation $(\sim 20 \mu \mathrm{g})$ was separated in Native (7\% resolving and 5\% stacking) [30], and SDS-PAGE (10\% resolving and 5\% stacking) gels at $140 \mathrm{~V}$ for $1 \mathrm{hr}$. At the end of electrophoresis, gels were stained with $0.2 \%$ Colloidal Coomassie Brilliant Blue G-250 as described [31, 32].

To complement the results of SDS PAGE, same samples were also subjected to SEC FPLC as ideally described [3]. SEC is a chromatographic technique that follows the principle of separation of molecules based on their sizes. Elution of proteins and peptides occurs in descending order of molecular weight i.e. large molecules elute first followed with the smaller ones. Briefly, crude protein samples were centrifuged at 14,000 rpm for 15 min and the supernatant was subjected to Fast Protein Liquid Chromatography (AKTA-Basic FPLC, GE Healthcare, UK) using SEC TSK-3000SW column (300 × $7.5 \mathrm{~mm} ; 10 \mu$; Tosoh Bioscience, USA). The column was equilibrated and eluted with $100 \mathrm{mM}$ phosphate buffer, $\mathrm{pH}$ 7.4. The flow rate was maintained at $0.4 \mathrm{ml} / \mathrm{min}$ and the eluted peaks were monitored at $280 \mathrm{~nm}$ for proteins and $340 \mathrm{~nm}$ specific absorbance for copper containing oxygen transport protein i.e. hemocyanins. The comparative analysis of the chromatograms was performed using the software UNICORN-5 (GE Healthcare, UK).

\subsection{Estimation of Total Carbohydrate, Protein and Lipid}

For carbohydrate estimation, $1 \mathrm{~g}$ whole soft tissue (wet weight) was homogenized in $10 \mathrm{ml}$ of phosphate buffer (100 $\mathrm{mM}, \mathrm{pH}$ 7.4). 10\% Trichloroacetic Acid (TCA) was added to precipitate the total proteins and the tubes were left for 30 min at room temperature. The mixture was centrifuged at $14000 \mathrm{rpm}$ for $15 \mathrm{~min}$. The supernatant was used for the quantification of carbohydrates via phenol-sulphuric acid method as described in another study [33]. The total protein from the pellets was estimated by Folin - Ciocalteu Phenol method [34]. The extraction of total lipids in the muscle was made by chloroform-methanol mixture and total lipid estimation was carried out by a colorimetric method [35]. Biometric differences among the three Thais sp. were analyzed by the one-way analysis of variance ANOVA [3, 36].

\subsection{Amino Acid Analysis}

The amino acid analysis was performed following the protocol described by Horwitz and Latimer [37]. Dried samples were first meshed $(1 \mathrm{mg})$ and followed with acid hydrolysis under vacuum treated with hydrochloric acidphenol solution $(6 \mathrm{~N})$ at $110{ }^{\circ} \mathrm{C}$ for $18-24 \mathrm{~h}$. The hydrolyzed samples after washing with water were evaporated to dryness on a rotary evaporator (BÜCHI, Switzerland). The total volume of the samples was made up to $10 \mathrm{ml}$ with deionized water, syringe filtered $(0.22 \mu \mathrm{m}$, PVDF, Millipore USA) and directly diluted in buffer-A, prior to injection $(20 \mu \mathrm{l})$ into the amino acid analyzer. The analysis was performed on the amino acid analyzer (10A, Shimadzu Japan) equipped with Shim-Pack Amino-Na column (4.6 mm, I.D x $100 \mathrm{~mm}$ ) packed with strong cation exchange resin (i.e. styrene divinylbenzene copolymer with sulphonic groups). Sample injection was made by the auto-injector SIL-10ADVP. The composition of the mobile phase was buffer-A ( $0.2 \mathrm{~N}$ sodium citrate), buffer-B ( $0.6 \mathrm{~N}$ sodium citrate and $0.2 \mathrm{M}$ boric acid), and buffer-C (0.2M NaOH). Ammonia trap column (Shim-pack ISC-30/SO504 Na) was used prior to column elution. Measurement was made at $\mathrm{Ex}=350 \mathrm{~nm}$ and $\mathrm{Em}=450 \mathrm{~nm}$ via fluorescence detector $(\mathrm{RF}-10 \mathrm{~A}$ $\mathrm{XL}$ ). The temperature of the column oven was adjusted at $60{ }^{\circ} \mathrm{C}$. This detection was made by post-column fluorescence derivatization with $o$-phthalaldehyde (OPA)/N-acetylcysteine (reaction reagent).

\subsection{Fatty Acids Extraction and GC Analysis}

Dried samples were meshed and soaked in a suitable quantity of n-Hexane for $24 \mathrm{~h}$ followed with sonication for $3 \mathrm{~h}$ and filtered and rotary evaporated. The resulted residual oils were collected and subjected to ester preparation. The extracted specimens were transferred to the conical flask $(50 \mathrm{ml})$, fixed with a suitable water-cooled reflux condenser and a magnetic stirrer bar. $4 \mathrm{ml}$ of methanolic sodium hydroxide $(0.5 \mathrm{~N})$ solution was added. $5 \mathrm{ml}$ of boron trifluride (methanolic) was then added in the above soluble solution and refluxed. Later, $4 \mathrm{ml} \mathrm{n}$-Hexane was further added through the condenser and refluxed for $1 \mathrm{~min}$. After cooling, the condenser was removed and 15 ml saturated sodium chloride solution was added, mixed and allowed for layer separation. The $n$-Hexane layer was passed through $0.1 \mathrm{~g}$ anhydrous sodium sulphate (previously washed with $n$-Hexane). The above solution was then transferred into a volumetric flask and diluted with $n$-Hexane. The fatty acid composition was determined using Gas Chromatograph (Shimadzu-2014, Japan) equipped with a Supelco Sp238 column (30 m x $0.25 \mu \mathrm{m}$ x $0.2 \mu \mathrm{m})$. The chromatogram was analyzed via software GC solution by comparing it with known standards. 


\section{RESULTS}

\subsection{Variations in Gastropods Biomass}

The species of gastropod found at Buleji showed a higher biomass (number of animals $/ \mathrm{m}^{2}$ and tissue weight $\mathrm{g} / \mathrm{m}^{2}$ ) in comparison to the biomass of the same species found at Paradise Point (Table $\mathbf{1}$ and 2). The difference in biomass may be attributed to the subtle variations in food availability at the two sites. The rocky coast of Buleji is rich in algal population as compared to Paradise Point where the algal population is less dense. Previous studies have also revealed that the population structure of the gastropods species differed between shores and this variation in size has been correlated to the increase in the algal productivity [20]. The other possible reason why the fauna at Paradise Point is scant may probably relate to the location of Karachi Nuclear Power Plant (KNPP) at this coast operational since 1972.

Table 1. Variation in the number of animals and tissue dry weight of Thais sp. during the study period of October 2013 to September 2014 at Buleji and Paradise Point.

\begin{tabular}{|c|c|c|c|c|}
\hline \multirow{2}{*}{ Species } & \multicolumn{2}{|c|}{ Animal Number $/ \mathbf{m}^{2}$} & \multicolumn{2}{c|}{ Dry Tissue Weight $\left(\mathbf{g} / \mathbf{m}^{2}\right)$} \\
\cline { 2 - 5 } & Buleji & Paradise Point & Buleji & Paradise Point \\
\hline Thais bufo & 3 & - & 7.8 & 0.4 \\
\hline Thais hippocastanum & 12.7 & 0.7 & 29 & 8.2 \\
\hline Thais rudolphi & 28 & 3.7 & 37.1 & - \\
\hline
\end{tabular}

Table 2. Seasonal variation in the total weight $\left(\mathrm{g} / \mathrm{m}^{2}\right)$ of Thais sp. during the period from October 2013 to September 2014 at Buleji.

\begin{tabular}{|c|c|c|c|c|c|c|c|c|c|c|c|c|c|}
\hline Species & Oct'13 & Nov'13 & Dec'13 & Jan'14 & Feb'14 & Mar'14 & Apr'14 & May'14 & Jun'14 & Jul'14 & Aug'14 & Sep'14 & Total \\
\hline T. bufo & - & - & 1.49 & 1.67 & - & - & 2.08 & - & - & - & 2.50 & - & 7.74 \\
\hline T.hippocastanum & - & 6.60 & 0.74 & 6.84 & - & 9.03 & - & 6.70 & - & - & - & 4.16 & 34.07 \\
\hline T. rudolphi & 2.40 & - & 2.62 & 8.37 & 5.83 & 7.63 & 3.5 & - & 6.74 & - & - & - & 37.09 \\
\hline
\end{tabular}

\subsection{Scanning Electron Microscopic Observation}

Three major and predominantly found Thais $s p$. were collected and preliminarily identified by shell morphology (Fig. 1B). SEM analysis of the shells microstructure revealed distinct surfaces but very identical combination of various elements which provide protection against environmental stress and offers a mechanical barrier. Thus SEM-EDX analysis revealed the presence of $\mathrm{C}, \mathrm{O}, \mathrm{K}, \mathrm{Ca}, \mathrm{Na}, \mathrm{Si}, \mathrm{Mg}, \mathrm{Al}$ and $\mathrm{Fe}$ in the shell microstructures (Fig. S1). The shell of T. bufo comprises $\mathrm{C}, \mathrm{O}, \mathrm{Na}, \mathrm{Ca}, \mathrm{Si}, \mathrm{Mg}$ and $\mathrm{Al}$. While T. hippocastanum shell microstructure showed the presence of $\mathrm{C}$, $\mathrm{O}, \mathrm{Ca}, \mathrm{Na}, \mathrm{Si}$, and $\mathrm{Al}$, the T. rudolphi comprises all the above-mentioned elements with the addition of Fe (Table S2).

\subsection{PCR Amplification, RFLP and DNA Sequencing}

PCR amplification of the three molecular marker genes (i.e. COI, 16S rDNA and Histone $\mathrm{H}_{3}$ ) was performed with great success. The product size of $16 \mathrm{~S}$ rDNA was also found slightly different in all species i.e. $\sim 522$ bp in T. bufo, $\sim 527 \mathrm{bp}$ in T. hippocastanum and $\sim 520 \mathrm{bp}$ in T. rudolphi (Fig. S2A). Likewise, PCR amplified products of COI gene which was expected to be around $\sim 750$ bp size effectively amplified in all three Thais species and showed subtle variations in size (Fig. S2B). In contrast, the amplified Histone $\mathrm{H}_{3}$ gene of three Thais species is presented in Fig. (S2C) which shows very similar and expected product sizes of around $\sim 380 \mathrm{bp}$. Moreover, restriction patterns obtained for the 16S rDNA and COI genes showed that all three Thais sp. have different restriction sites as a unique restriction pattern was observed in each case. However, 16S rDNA and COI genes of Thais rudolphi were not digested by the enzyme Alu-I, since it probably does not possess any restriction site for this restriction enzyme which again supports the genetic differences among species (Fig. S2A and B).

Moreover, differences in morphologies were further confirmed by DNA sequencing and phylogenetic analysis of 16S rDNA and COI genes (Fig. S3). All sequences obtained were deposited in NCBI gene databank and were also provided with the accession numbers in Table $\mathbf{S 1}$.

\subsection{Biochemical Characterization by Protein Fingerprinting}

For protein fingerprinting, total hemolymph proteins collected from three specimens were subjected to comparative electrophoretic (Native and SDS-PAGE) and chromatographic (SEC FPLC) analysis. As expected, the high molecular 
mass oxygen carrier glycol-metalloprotein (i.e. hemocyanins) was found to be the major hemolymph protein and common in all (Fig. S4). Besides, the presence of two typical high mass Hcy subunit bands around $\sim 380-400 \mathrm{kDa}$, other low abundant protein bands with molecular mass ranging from 45-95 kDa and 20-32 kDa were found to be highly distinct in all the three species of the genus Thais (Fig. S4). In case of chromatography, specific wavelength detection of hemocyanin (i.e. $340 \mathrm{~nm}$ ) additionally segregates the Hcy with other distinct proteins (Fig. S5).

\subsection{Quantitative Estimation of Protein, Carbohydrate and Lipids}

The total protein contents in T. bufo, T. hippocastanum and T. rudolphi were found to be 36.02 $\pm 6.94,28.52$ \pm 4.76 and $28.74 \pm 2.01 \mathrm{mg} / \mathrm{g}$, respectively. No significant difference was observed in the total protein content among the three species $(\mathrm{F}=1.004 ; \mathrm{df}=2 ; \mathrm{P}=0.420)$. The total carbohydrate portions in $T$. bufo, $T$. hippocastanum and T. rudolphi were estimated to be $5.32 \pm 1.46,15.67 \pm 2.48$ and $17.26 \pm 5.21 \mathrm{mg} / \mathrm{g}$, respectively. The carbohydrate content also showed no significant difference among the three species $(\mathrm{F}=$ 0.347; $\mathrm{df}=2 ; \mathrm{P}=0.719)$. Likewise, the total lipid contents were quantified as $17.11 \pm 2.43,15.46 \pm 1.83$ and $14.39 \pm 2.60 \mathrm{mg} / \mathrm{g}$ in T. bufo, T. hippocastanum and T. rudolphi, respectively. However, no significant difference was found in the tissue lipid contents of the three species $(\mathrm{F}=0.043 ; \mathrm{df}=2 ; \mathrm{P}=0.958)$. While the total content of proteins in the tissue was found with the highest proportion in comparison to carbohydrate and lipid (Fig. 2).

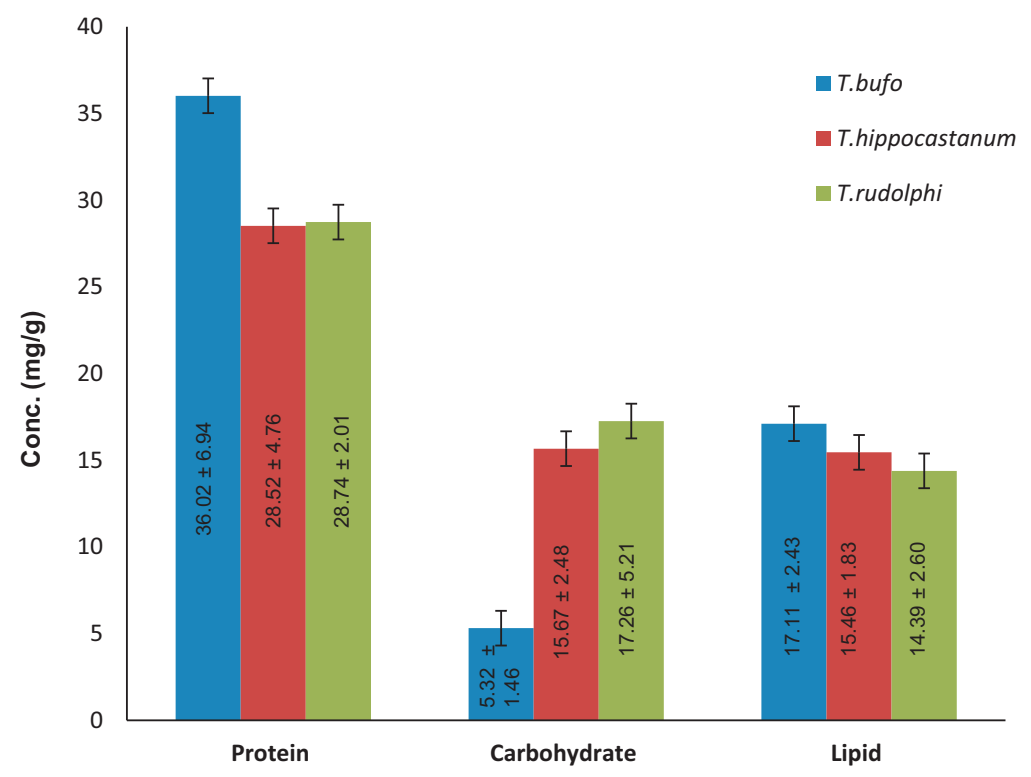

Fig. (2). Estimation of total proteins, carbohydrates and lipids in the tissues of T. bufo, T. hippocastanum and T. rudolphi. Data is expressed as mean \pm standard deviation of the triplicate of triplicate experiments.

\subsection{Amino Acid Composition}

Amino acid compositions of the three Thais $s p$. exhibited the presence of 17 amino acids including both essential and non-essential amino acids (Table 3). Among them, 7 were essential amino acids and remaining 10 were nonessential amino acids. The total amino acid compositions of muscle (including essential and non-essential amino acids) was found to be 653.2, 709.2 and $693.8(\mathrm{mg} / \mathrm{g})$ in T. bufo, T. hippocastanum and T. rudolphi, respectively.

Table 3. Amino acid composition of three major Thais sp.

\begin{tabular}{|c|c|c|c|}
\hline Amino acids & Thais bufo & $\begin{array}{c}\text { Thais hippocastanum } \\
(\mathrm{mg} / \mathrm{g})\end{array}$ & Thais rudolphi \\
\hline \multicolumn{4}{|c|}{ Non-essential amino acids } \\
\hline Aspartic acid & 88.4 & 22.6 & 22.9 \\
\hline Serine & In trace & 3.8 & 4.5 \\
\hline Glutamic acid & 144.2 & 228 & 230.4 \\
\hline Glycine & 65.3 & 74.6 & 73.7 \\
\hline
\end{tabular}


(Table $\square$ ) contd.....

\begin{tabular}{|c|c|c|c|}
\hline Amino acids & Thais bufo & $\begin{array}{c}\text { Thais hippocastanum } \\
(\mathrm{mg} / \mathrm{g})\end{array}$ & Thais rudolphi \\
\hline Alanine & 75.8 & 83.2 & 81.3 \\
\hline Cysteine & 7.1 & 9 & 5.1 \\
\hline Tyrosine & 7.6 & 16.6 & 28.5 \\
\hline Proline & 29.3 & 27.8 & 26.2 \\
\hline Arginine & In trace & In trace & In trace \\
\hline \multicolumn{4}{|c|}{ Essential amino acids } \\
\hline Threonine & 3 & 0.9 & 1.3 \\
\hline Valine & 19.4 & 20 & 14.2 \\
\hline Methionine & 6.3 & 14.9 & 5.4 \\
\hline Isoleucine & In trace & 6.1 & In trace \\
\hline Leucine & 30.3 & 40.3 & 31.7 \\
\hline Phenylalanine & 8.6 & 15.3 & 13.4 \\
\hline Histidine & 3.8 & 4.4 & 2.6 \\
\hline Tryptophan & 130.1 & 110.2 & 123.2 \\
\hline Lysine & 34 & 31.5 & 29.4 \\
\hline Total & 653.2 & 709.2 & 693.8 \\
\hline
\end{tabular}

\subsection{Fatty Acid Composition}

A total of nine individual fatty acids were determined in the muscle of T. bufo, T. hippocastanum and T. rudolphi Table (4). Among those Saturated Fatty Acids (SFA) included; myristic acid (14:0), palmitic acid (16:0), stearic acid (18:0), Eicosanoic Acid (20:0) and monoenoic fatty acids include; palmitoleic acid (16:1), oleic acid (18:1), while Polyunsaturated Fatty Acids (PUFAs) include linolenic acid (18:3), eicosapentaenoic acid (20:5) and docosahexaenoic acid (22:6). The fatty acids were presented as the relative amount in the percent of total fatty acids. The total Saturated Fatty Acids (SFA) constituent in T. bufo, T. hippocastanum and T. rudolphi were estimated to be 51.9\%, 29.4\% and $26.2 \%$, respectively. The Monounsaturated Fatty Acids (MUFAs) constituted about 12.4\%, 5.6\% and 1.4\% of the total fatty acids in T. bufo, T. hippocastanum and T. rudolphi (respectively), while PUFAs in T. bufo, T. hippocastanum and T. rudolphi were estimated to be $3.5 \%, 11.3 \%$ and $8.4 \%$, respectively.

Table 4. Fatty acid profiles of three major Thais sp. PUFAs- polyenoic unsaturated fatty acids. SFAs- saturated fatty acids; MUFAs; monoenoic unsaturated fatty acids.

\begin{tabular}{|c|c|c|c|}
\hline Fatty Acids & Thais bufo & $\begin{array}{c}\text { Thais hippocastanum } \\
(\% \text { total FF) }\end{array}$ & Thais rudolphi \\
\hline \multicolumn{4}{|c|}{$\underline{\text { Saturated Fatty Acids }}$} \\
\hline Myristic acid (C14:0) & 3.9 & 2.8 & 2.4 \\
\hline Palmitic acid (C16:0) & 40.1 & 14.3 & 14.3 \\
\hline Stearic acid $(\mathrm{C} 18: 0)$ & 7.7 & 12.1 & 9.0 \\
\hline Eicosanoic acid (C20:0) & 0.2 & 0.2 & 0.5 \\
\hline$\sum$ SFA & 51.9 & 29.4 & 26.2 \\
\hline \multicolumn{4}{|c|}{ Monounsaturated Fatty Acids } \\
\hline Oleic Acid (C18:1) & 8.5 & 4.6 & 1.4 \\
\hline Palmitoleic acid (C16:1) & 3.9 & 1.0 & - \\
\hline$\sum$ MUFA & 12.4 & 5.6 & 1.4 \\
\hline \multicolumn{4}{|c|}{ Polyenoic unsaturated Fatty Acids } \\
\hline Linolenic acid (C18:3) & 3.3 & 8.4 & 6.3 \\
\hline Eicosapentaenoic acid (C20:5) & 0.2 & 1.2 & - \\
\hline Decosahexanoic acid (C22:6) & - & 1.7 & 2.1 \\
\hline$\sum$ PUFA & 3.5 & 11.3 & 8.4 \\
\hline
\end{tabular}

\section{DISCUSSION}

Three predominant species of genus Thais (i.e. T. bufo, T. hippocastanum and T. rudolphi) collected from the low tidal zone of Buleji and Paradise point of the Sindh Coast of Pakistan were subjected for detailed biomass assessment, morphological and molecular identification, nutritive value and biochemical characterization. 


\subsection{Micro-Morphological And Molecular Identification}

Elemental composition established by SEM-EDX was consistent in the three shells. It showed a prominent calcium peak and smaller peaks corresponding to other inorganic elements (i.e. $\mathrm{Mg}, \mathrm{Na}, \mathrm{P}, \mathrm{Al}, \mathrm{Si}, \mathrm{Fe}$ ). $\mathrm{Ca}$ was found as the dominant element in the microstructure of $T$. bufo, T. hippocastanum and T. rudolphi. The complexity in the microstructures of the shell is also considered as an evidence for their shallow water origin [38]. The shells of marine mollusk are composed of biomaterials and organic matrix components which are secreted by mantle epithelial cells [39]. However, physical or ecologically driven barriers are sometimes involved in gene flow during speciation which is very common in marine gastropods $[40,41]$.

Mitochondrial DNA analysis is often successfully used for comparing the nucleotide sequences among the population e.g. turban shells found along the exposed and protected shore, thus confirming the environmental factor in gene flow [42]. The genetic markers used for the identification of three species, i.e. two mitochondrial genes (COI and $16 \mathrm{~S}$ rDNA) and one nuclear gene (H3) supported very well in establishing phylogeny and exploring common ancestors.

The phylogenetic analysis of both COI and 16S rDNA involved 13 and 29 nucleotide sequences. T. bufo and $T$. hippocastanum were found to share the same clade along with Thalessa savignyi, whereas T. rudolphi was found in a different clade with Purpura persica. The sequence of COI gene and 16S rDNA from two gastropods T. hippocastanum and T. rudolphi submitted in NCBI Genebank was taxonomically revised as Thalessa virgata and Purpura rudolphi, respectively. This showed the genetic differentiation among the three studied Thais $s p$. which belong to three different genera and were earlier considered to be three different species of the same genus. It can be concluded from the above results that the genus Thais still requires a thorough taxonomic revision.

\subsection{Total Protein, Carbohydrate and Lipids}

Overall, nutrients in the tissues of subjected gastropods species from the genus Thais, were found with high protein content with lipid and carbohydrates. A previous report on the biochemical composition of gastropod i.e. Thais lamellosa which is the only studied Thais sp. for the biochemical composition so far [43] showed the level of protein, carbohydrate and lipid in the Testis, digestive gland, visceral mass and foot. However, the micro-Kjeldahl technique used in this study is quite old and measures the total nitrogen, thus showing relatively high concentrations of macronutrients as compared to our data. Babylonia spirata, which belongs to family Babyloniidae, was also studied for its nutritive value and found to have $53.86 \%$ of protein, $16.65 \%$ carbohydrate and $9.3 \%$ lipid in its body tissue [6]. In another such study on Burssa spinosa, the percent composition of macronutrients in foot, mantle and gonad was estimated and the gonad was found to possess the maximum content of $27.91 \%$ protein, $7.7 \%$ carbohydrate and $4.9 \%$ lipid [44]. A recently reported study on the Siphonaria sp. showed the level of protein, carbohydrate and lipid as 107.1, 36.1 and $92.5 \mathrm{mg} / \mathrm{g}$, respectively [3]. On the other hand, three species of the genus Thais showed close similarity in their amino acid composition. In general, all species presented an almost similar profile of amino acids except for $T$. bufo which contains a trace amount of serine and isoleucine and T. rudolphi which also possess isoleucine though in trace amount.

\subsection{Amino Acid Composition}

Amino acids are a mandatory part of the human diet. They have a significant role as a constituent of proteins, in the regulation of several cellular processes metabolites in the homeostasis of an organism and as precursors of other molecules, such as hormones and nitrogenous bases. Since humans cannot synthesize some of them (i.e. essential amino acids), therefore they must be supplied via a diet rich in these building blocks $[45,46]$. Out of the nine reported essential amino acids, tryptophan was found to be the maximum, i.e. $130.1,110.2$ and $123.2(\mathrm{mg} / \mathrm{g})$ in $T$. bufo, $T$. hippocastanum and T. rudolphi, respectively. Arginine was found with the negligible amount in the three Thais sp. and isoleucine was also determined with trace amount in T. bufo and T. rudolphi. Moreover, glutamic acid was found with the highest proportion among the non-essential ones, i.e. 144.2, 228 and $230.4(\mathrm{mg} / \mathrm{g})$ in T. bufo, T. hippocastanum and T. rudolphi, respectively. In comparison to other gastropods, Babylonia spirata total amino acid composition (including both essential and non-essential amino acids) is reported as low as $9.91 \mathrm{mg} / \mathrm{g}$ [6], whereas in Bursa spinosa $50.01 \%$ essential amino acids and $46.79 \%$ non-essential amino acid were reported as the highest [44].

\subsection{Fatty Acid Composition}

Fatty acids which are the essential nutrient source and major constituents of the membrane also play a vital role as metabolic and signaling mediators. Marine organisms are being pursued as an alternative source of polyunsaturated 
fatty acids (PUFAs) with increasing demand of food. Among PUFA, $₫ 3$ compounds are particularly very significant for human health and prevent many cardiovascular diseases [44, 46]. Several studies based on the lipid and fatty acid composition of gastropods reported that they are perfectly alternative source of palmitic, arachidonic, eicosapentaenoic and docosahexaenoic acids [9, 47, 48].

The total fatty acid composition in T. bufo, T. hippocastanum and T. rudolphi was found to be $67.8 \%, 46.3 \%$ and $36 \%$, respectively. In T. bufo, SFA was the dominant group followed by MUFA and PUFA, whereas in case of $T$. hippocastanum and T. rudolphi, SFA contributed the most, followed by PUFA and MUFA. Among the nine fatty acids determined in Thais sp., eicosapentaenoic and palmitoleic acids were not found in T. rudolphi and docosahexaenoic acid was missing in T. bufo. For comparison, Siphonaria sp. revealed $27.40 \%$ to $28.99 \%$ SFA and around $45.97 \%$ to $47.84 \%$ PUFA and the type of fatty acids detected were very similar to the fatty acid profile of gastropods species subjected in the present study [48]. In another such study, Babu et al. [45] reported the fatty acid profile of T. dolium that showed SFA, MUFA and PUFA to be 3.13\%, 1.05\% and 3.55\% (respectively), whereas P. glaucum showed SFA, MUFA and PUFA to be $2.22 \%, 0.96 \%$ and $3.16 \%$, respectively. The stress of heavy metals and pollution is encountered as one of the reasons behind the biochemical alterations in the marine gastropods. Moreover, the biochemical composition of marine gastropods also deviates because of several other factors, like access of food, size of the animal, sex, stage of maturity and/or seasonal variations [6]. Increasing pollution and consumption of toxic compounds, like Tributyltin and Triphenyltin (TBT/ TPhT) by marine organism may also lead to imposex in female gastropods which also alters the biochemical composition and the nutritional status of marine gastropods badly [47, 49]. Not only the biochemical composition of the gastropod species, but also the flora and fauna along the Karachi coast are being threatened due to the increasing pollution and anthropogenic activities.

Thus, the present study clearly demonstrates that shell morphology along with even SEM- EDS is not alone sufficient to distinguish the closely related species in a genus and genetic evidence through molecular analysis remains the gold standard. Likewise, electrophoretic data alone is quite complementary by using a combination of native-PAGE ( $\mathrm{pH}$ 6.8) with SDS-PAGE electrophoresis under dissociating (SDS, $\mathrm{pH}$ 8.8) and dissociated/denaturing (SDS plus DTT, $\mathrm{pH}$ 8.8) conditions. On the other hand, size exclusion chromatography of the same batch of samples nicely complements the electrophoresis results. Thus, the two genotypic and phenotypic techniques hand-to-hand provide excellent DNA/protein fingerprints for the chemo-taxonomical differentiation of the genus Thais.

\section{CONCLUSION}

In conclusion, the present study shows a comprehensive analysis of the identification and biochemical constituents of the major Thais sp. which is very significant since it reflects the nutritive status. Taken together, our findings demonstrate that the selected gastropods subjected in the present study can be utilized economically as a possible source of nutrition in the developing countries to overcome the increasing shortage of food and/or feed. A significant amount of food can be supplied to humans or feed if marine resources are being utilized efficiently. Unfortunately, the overall ecosystem of marine is being threatened due to the increasing marine pollution. Therefore, in most countries, the marine resources are being wasted and cannot be utilized for its possible use as food and/or feed to meet the increasing demand for food with increasing population.

\section{ETHICS APPROVAL AND CONSENT TO PARTICIPATE}

Not applicable.

\section{HUMAN AND ANIMAL RIGHTS}

No animals/humans were used for studies that are the basis of this research.

\section{CONSENT FOR PUBLICATION}

Not applicable.

\section{CONFLICT OF INTEREST}

The authors declare no conflict of interest, financial or otherwise. 


\section{ACKNOWLEDGMENTS}

This project was financially supported by Pakistan Science Foundation (PSF/Res/S-KU/Bio (422) to S.A Ali and Z Ayub) and Higher Education Commission (HEC No. 20-1339/R\&D/09; to SA Ali) Islamabad, Pakistan.

\section{SUPPLEMENTARY MATERIAL}

Supplementary material is available on the publishers Website along with the published article.

\section{REFERENCES}

[1] Barkati S, Rahman S. Species composition and faunal diversity at three sites of Sindh Mangroves. Pak J Zool 2005; 37(1): 17-31.

[2] Afsar N, Siddiqui G, Ayub Z. Update of records of selected prosobranch gastropod species found along the coasts of sindh and balochistan Pakistan. Pak J Zool 2012; 44(1): 267-75.

[3] Ali SA, Ayub Z, Bano A, Fatima H. Biochemical studies on siphonaria (gastropoda: pulmonata) from the karachi coast of North Arabian Sea. Pak J Zool 2011; 43(6): 1085-93.

[4] Khan TMA, Razzaq DA, Chaudhry Q-U-ZUZ, Quadir DA, Kabir A, Sarker MA. Sea level variations and geomorphological changes in the coastal belt of Pakistan. Mar Geod 2002; 25(1): 159-74. [http://dx.doi.org/10.1080/014904102753516804]

[5] Adeyeye EI. Waste yield, proximate and mineral composition of three different types of land snails found in Nigeria. Int J Food Sci Nutr 1996; 47(2): 111-6. [http://dx.doi.org/10.3109/09637489609012572] [PMID: 8833175]

[6] Periyasamy N, Srinivasan M, Devanathan K, Balakrishnan S. Nutritional value of gastropod Babylonia spirata (linnaeus, 1758) from thazhanguda, southeast coast of India. Asian Pac J Trop Biomed 2011; 1: 249-52. [http://dx.doi.org/10.1016/S2221-1691(11)60164-0] [PMID: 23569768]

[7] Ab Lah R, Smith J, Savins D, Dowell A, Bucher D, Benkendorff K. Investigation of nutritional properties of three species of marine turban snails for human consumption. Food Sci Nutr 2016; 5(1): 14-30.

[http://dx.doi.org/10.1002/fsn3.360] [PMID: 28070312]

[8] España MS, Rodríguez EM, Romero CD. Sodium, K, Ca, Mg, Fe, Cu, and Zn concentrations in molluscs from the magellan strait (Chile): Their contribution to dietary intake. Int J Food Sci Nutr 2005; 56(5): 337-47. [http://dx.doi.org/10.1080/09637480500170598] [PMID: 16236595]

[9] Zhukova NV. Lipids and fatty acids of nudibranch mollusks: Potential sources of bioactive compounds. Mar Drugs 2014; 12 (8): 4578-92. [http://dx.doi.org/10.3390/md12084578] [PMID: 25196731]

[10] Arancibia S, Espinoza C, Salazar F, et al. A novel immunomodulatory hemocyanin from the limpet Fissurella latimarginata promotes potent anti-tumor activity in melanoma. PLoS One 2014; 9(1): e87240. [http://dx.doi.org/10.1371/journal.pone.0087240] [PMID: 24466345]

[11] Coates CJ, Nairn J. Diverse immune functions of hemocyanins. Dev Comp Immunol 2014; 45(1): 43-55. [http://dx.doi.org/10.1016/j.dci.2014.01.021] [PMID: 24486681]

[12] Gesheva V, Chausheva S, Stefanova N, et al. Helix pomatia hemocyanin: A novel bio-adjuvant for viral and bacterial antigens. Int Immunopharmacol 2015; 26(1): 162-8. [http://dx.doi.org/10.1016/j.intimp.2015.03.011] [PMID: 25799956]

[13] Claremont M, Reid DG, Williams ST. A molecular phylogeny of the rapaninae and ergalataxinae (Neogastropoda: Muricidae). J Molluscan Stud 2008; 74(3): 215-21.

[http://dx.doi.org/10.1093/mollus/eyn005]

[14] Barco A, Claremont M, Reid DG, et al. A molecular phylogenetic framework for the Muricidae, a diverse family of carnivorous gastropods. Mol Phylogenet Evol 2010; 56(3): 1025-39. [http://dx.doi.org/10.1016/j.ympev.2010.03.008] [PMID: 20226866]

[15] Claremont M, Vermeij GJ, Williams ST, Reid DG. Global phylogeny and new classification of the Rapaninae (Gastropoda: Muricidae), dominant molluscan predators on tropical rocky seashores. Mol Phylogenet Evol 2013; 66(1): 91-102. [http://dx.doi.org/10.1016/j.ympev.2012.09.014] [PMID: 23026810]

[16] Tewari A, Raghunathan C, Joshi HV, Khambhaty Y. Imposex in rock whelks Thais and Ocenebra species (Mollusca, Neogastropoda, Muricidae) from Gujarat coast. Indian J Geo-Mar Sci 2002; 31: 321-8.

[17] Teske PR, Papadopoulos I, Mmonwa KL, et al. Climate-driven genetic divergence of limpets with different life histories across a southeast African marine biogeographic disjunction: Different processes, same outcome. Mol Ecol 2011; 20(23): 5025-41. [http://dx.doi.org/10.1111/j.1365-294X.2011.05307.x] [PMID: 22017655]

[18] Kumbhar JV, Rivonker CU. A new record of Morula anaxares with a description of the radula of three other species from Goa, central West Coast of India (Gastropoda: Muricidae). Turk J Fish Aquat Sci 2012; 12: 189-97. [http://dx.doi.org/10.4194/1303-2712-v12_1_22] 
[19] Teske PR, Barker NP, McQuaid CD. Lack of genetic differentiation among four sympatric southeast African intertidal limpets (Siphonariidae): Phenotypic plasticity in a single species? J Molluscan Stud 2007; 73: 223-8. [http://dx.doi.org/10.1093/mollus/eym012]

[20] Ahmed M, Hameed S. A comparative study on the biomass of animals and seaweeds of the rocky shore of Buleji near Karachi, Pakistan. Pak J Biol Sci 1999; 2(2): 365-9. [http://dx.doi.org/10.3923/pjbs.1999.365.369]

[21] Hameed S, Ahmed M. Distribution and abundance of intertidal macro-invertebrates on the rocky bench of Pacha, near Karachi. Int J Ecol Environ Sci 2000; 26: 149-200.

[22] Khan MD, Dastagir SH. On the mollusca: Gastropds fauna of Pakistan. Rec Zool Surv Pak 1970; $2: 17-129$.

[23] Dance SP. The Encyclopedia of Shells. London, UK: Blandford Press 1974.

[24] Bosch DT, Dance P, Moolenbeek RG, Oliver PG. Sea shells of Eastern Arabia 1995.

[25] Rech JA, Pigati JS, Lehmann SB, McGimpsey CN, Grimley DA, Nekola JC. Assessing open-system behavior of 14C in terrestrial gastropod shells. Radiocarbon 2011; 53: 325-35. [http://dx.doi.org/10.1017/S0033822200056587]

[26] Nakano T, Yazaki I, Kurokawa M, Yamaguchi K, Kuwasawa K. The origin of the endemic patellogastropod limpets of the Ogasawara Islands in the northwestern Pacific. J Molluscan Stud 2009; 75(1): 87-90.

[http://dx.doi.org/10.1093/mollus/eyn036]

[27] Dayrat B, Conrad M, Balayan S, et al. Phylogenetic relationships and evolution of pulmonate gastropods (Mollusca): New insights from increased taxon sampling. Mol Phylogenet Evol 2011; 59(2): 425-37. [http://dx.doi.org/10.1016/j.ympev.2011.02.014] [PMID: 21352933]

[28] Tamura K, Nei M, Kumar S. Prospects for inferring very large phylogenies by using the neighbor-joining method. Proc Natl Acad Sci USA 2004; 101(30): 11030-5. [http://dx.doi.org/10.1073/pnas.0404206101] [PMID: 15258291]

[29] Kumar S, Stecher G, Tamura K. MEGA7: Molecular evolutionary genetics analysis version 7.0 for bigger datasets. Mol Biol Evol 2016; 33(7): 1870-4. [http://dx.doi.org/10.1093/molbev/msw054] [PMID: 27004904]

[30] Ali SA, Zaidi ZH, Abbasi A. Oxygen transport proteins: I. Structure and organization of hemocyanin from scorpion (Buthus sindicus). Comp Biochem Physiol A Physiol 1995; 112(1): 225-32. [http://dx.doi.org/10.1016/0300-9629(95)00058-F] [PMID: 7553332]

[31] Ali SA, Yang DC, Jackson TNW, et al. Venom proteomic characterization and relative antivenom neutralization of two medically important Pakistani elapid snakes (Bungarus sindanus and Naja naja). J Proteomics 2013; 89: 15-23. [http://dx.doi.org/10.1016/j.jprot.2013.05.015] [PMID: 23714137]

[32] Ali SA, Jackson TNW, Casewell NR, et al. Extreme venom variation in Middle Eastern vipers: A proteomics comparison of Eristicophis macmahonii, Pseudocerastes fieldi and Pseudocerastes persicus. J Proteomics 2015; 116: 106-13. [http://dx.doi.org/10.1016/j.jprot.2014.09.003] [PMID: 25241240]

[33] DuBois M, Gilles KA, Hamilton JK, Rebers PA, Smith F. Colorimetric method for determination of sugars and related substances. Anal Chem 1956; 28(3): 350-6 [http://dx.doi.org/10.1021/ac60111a017]

[34] Lowry OH, Rosebrough NJ, Farr AL, Randall RJ. Protein measurement with the folin phenol reagent. J Biol Chem 1951; 193(1): 265-75. [PMID: 14907713]

[35] Barnes H, Blackstock J. Estimation of lipids in marine animals and tissues: Detailed investigation of the sulphophosphovanillin method for total lipids. J Exp Mar Biol Ecol 1973; 12: 103-18 [http://dx.doi.org/10.1016/0022-0981(73)90040-3]

[36] Fatima H, Ayub Z, Ali SA, Siddiqui G. Biochemical composition of the hemolymph, hepatopancreas, ovary, and muscle during ovarian maturation in the penaeid shrimps Fenneropenaeus merguiensis and F. penicillatus (Crustacea: Decapoda). Turk J Zool 2013; 37(3): 334-47.

[37] Horwitz W, Latimer GW. Amino Acids in feed, AOAC official method 994.12, Official methods of analysis of AOAC international. nineteenth ed. Maryland (USA): AOAC international press. 2012.

[38] Hrabánková I, Frýda J, Šepitka J, Sasaki T, Frýdová B, Lukeš J. Mechanical properties of deep-sea molluscan shell 2013. [http://dx.doi.org/10.1080/10255842.2013.815873]

[39] Auzoux-Bordenave S, Badou A, Gaume B, et al. Ultrastructure, chemistry and mineralogy of the growing shell of the european abalone Haliotis tuberculata. J Struct Biol 2010; 171(3): 277-90. [http://dx.doi.org/10.1016/j.jsb.2010.05.012] [PMID: 20553887]

[40] Bird CE, Holland BS, Bowen BW, Toonen RJ. Diversification of sympatric broadcast-spawning limpets (Cellana spp.) within the Hawaiian archipelago. Mol Ecol 2011; 20(10): 2128-41.

[http://dx.doi.org/10.1111/j.1365-294X.2011.05081.x] [PMID: 21481050] 
[41] Claremont M, Reid DG, Williams ST. Speciation and dietary specialization in Drupa, a genus of predatory marine snails (Gastropoda: Muricidae). Zool Scr 2012; 41(2): 137-49. [http://dx.doi.org/10.1111/j.1463-6409.2011.00512.x]

[42] Kurihara T, Shikatani M, Nakayama K, Nishida M. Proximate mechanisms causing morphological variation in a turban snail among different shores. Zool Sci 2006; 23(11): 999-1008. [http://dx.doi.org/10.2108/zsj.23.999] [PMID: 17189912]

[43] Stickle WB, Rouge B. The reproductive physiology of the intertidal prosobranch Thais lamellosa (Gmelin). II. Seasonal changes in biochemical composition. Biol Bull 1975; 148(3): 448-60. [http://dx.doi.org/10.2307/1540521] [PMID: 1156612]

[44] Babu A, Kesavan K, Annaduri D, Rajagopal S. Bursa spinosa-A mesogastropod fit for human consumption. Adv J Food Sci Tech 2010; 2(1): 79-83.

[45] Babu A, Venkatesan V, Rajagopal S. Fatty acid and amino acid compositions of the gastropods, Tonna dolium (linnaeus, 1758) and Phalium glaucum (linnaeus, 1758) from the gulf of mannar, southeast coast of India. Ann Food Sci and Techn 2011; 12: 159-63.

[46] Pereira DM, Valentão P, Teixeira N, Andrade PB. Amino acids, fatty acids and sterols profile of some marine organisms from Portuguese waters. Food Chem 2013; 141(3): 2412-7.

[http://dx.doi.org/10.1016/j.foodchem.2013.04.120] [PMID: 23870975]

[47] Afsar N, Siddiqui G, Ayub Z, Fatima H. Fatty acid profile of neogastropod species babylonia spirata from manora channel, the intensive shipping area of Pakistan. Int J Biol Biotechnol 2014; 11(1): 23-8.

[48] Bano A, Ayub Z, Siddiqui G. Fatty acid composition of three species of Siphonaria (Gastropoda: Pulmonata) in Pakistan. Pak J Zool 2014; 46(3): 813-8.

[49] Tan KS. Species checklist of muricidae (Mollusca: Gastropoda) in the south china sea. Raffles Bull Zool 2000; 8: 495-512.

(C) 2018 Ali et al.

This is an open access article distributed under the terms of the Creative Commons Attribution 4.0 International Public License (CC-BY 4.0), a copy of which is available at: (https://creativecommons.org/licenses/by/4.0/legalcode). This license permits unrestricted use, distribution, and reproduction in any medium, provided the original author and source are credited. 